\title{
Historical perspectives of The American Association for Thoracic Surgery: Norman E. Shumway, Jr (1923-2006)
}

\author{
James I. Fann, MD, ${ }^{a}$ and William A. Baumgartner, MD $^{\mathrm{b}}$
}

Norman E. Shumway, Jr, the 67th president of The American Association for Thoracic Surgery (AATS), was born on February 9, 1923, in Kalamazoo, Michigan, the only child of Norman and Laura Vander Vliet Shumway (Figure 1). At an early age, he and his family moved to Jackson, Michigan, where they established a dairy and diner. ${ }^{1-5}$ At Jackson High School, Dr Shumway was a member of the state championship debate team and the class valedictorian. Insightfully and prophetically, his yearbook picture was accompanied by the statement "Norman Shumway, Jr.a man of few words but great meaning." In 1942, Dr Shumway attended University of Michigan as a prelaw student. One year later, during World War II, he enlisted in the Army reserves with infantry training at Camp Wolters in Mineral Wells, Texas. Dr Shumway recounted that the end of the Army Medical Aptitude Test was capped with this existential question: "If you are chosen or pass this test, are you more interested in medicine or dentistry?" 3 From what he knew about the infantry, Shumway "was pretty sure they were going to need more doctors than dentists," so, he chose the former. The dental program eventually closed, and those who had checked the dentistry box were sent back to the infantry.

Assigned to Army Specialized Training, Dr Shumway completed 3 quarters of premedical studies at Baylor University in Waco, Texas. ${ }^{1-4}$ Because all military slots in medical school were full at the time, he served as a hospital orderly for 6 months before having the opportunity to enroll in Vanderbilt University Medical School, which was not on the original list of schools with military slots. ${ }^{3}$ Completion of medical school in 1949 led to surgical residency training at the renowned University of Minnesota under the direction of Dr Owen Wangensteen. Dr Shumway completed 2 years of residency before being assigned to the Air Force in 1951 during the Korean conflict, where he fulfilled his military obligation as a flight

\footnotetext{
From the Department of Cardiothoracic Surgery, ${ }^{\text {a }}$ Stanford University, Stanford, Calif; and the Division of Cardiothoracic Surgery, ${ }^{\mathrm{b}}$ Johns Hopkins University, Baltimore, Md.

Disclosures: Authors have nothing to disclose with regard to commercial support.

Received for publication Aug 15, 2011; accepted for publication Sept 15, 2011; available ahead of print Oct 19, 2011.

Address for reprints: James I. Fann, MD, Department of Cardiothoracic Surgery, Stanford University, 300 Pasteur Dr, Stanford, CA 94305 (E-mail: jfann@ stanford.edu).

J Thorac Cardiovasc Surg 2011;142:1299-302

$0022-5223 / \$ 36.00$

Copyright (C) 2011 by The American Association for Thoracic Surgery

doi:10.1016/j.jtcvs.2011.09.005
}

surgeon in Lake Charles, Louisiana. After returning to Minnesota, his interest in cardiac surgery intensified under the tutelage and inspiration of Drs C. Walton Lillehei and F. John Lewis. ${ }^{1,6,7}$ Other mentors were Drs Maurice Visscher and Jack Johnson, physiologists with whom he worked during his $2 \frac{1}{2}$ years in the laboratory. He received his doctorate in 1956 on the basis of his study of total body hypothermia, an area of interest of Dr Lewis, who had performed the first successful heart operation when he closed an atrial septal defect in a 5-year-old girl under total body hypothermia and inflow occlusion in 1952. ${ }^{7,8}$ At Dr Lillehei's 80th birthday celebration, Dr Shumway related, "I wish I knew them so well I could call them C and F, but actually to me they were always C. Walton Lillehei and F. John Lewis. They were the most spectacular and productive surgeons to come out of the University of Minnesota in the 1950s." 6 This was a heady period, and because of the number of attending surgeons scrubbed in for these cases and the many residents in the program, it was difficult to get hands-on training in cardiac surgery. At Minnesota, Dr Shumway first said and repeated many times later, "The most difficult thing about surgery-even heart surgery-is getting a chance to do it." ${ }^{, 9}$ In this educationally rich environment created by Dr Wangensteen, he admiringly recalled that Dr Wangensteen's "greatest attribute was that he had a total lack of envy"; he fully supported the young surgeons and "just basked in the reflected glory of their contributions." "3,6 When Dr Shumway finished his training, there were others who "had worked with Lillehei and who were closer to having a faculty position," leaving him without a position at Minnesota. ${ }^{3}$

In 1957, Dr Shumway joined an older, conservative surgeon at a community hospital in idyllic Santa Barbara, California. After being in private practice for 6 weeks and recognizing this mismatch, Shumway could not recall whether he "quit, was fired, or both," although by some accounts he was fired for "gross insubordination.",3,5 By chance, he was introduced to Dr Victor Richards, the chairman of surgery at Stanford-Lane Hospital in San Francisco, and in February 1958 he was hired to be an instructor in surgery with the responsibility of operating the dialysis machine in the evenings. Dr Frank Gerbode, 53rd AATS president, was the established cardiac surgeon at Stanford Hospital; consequently, Dr Shumway's adult cardiac surgical options were limited. Instead, with the support of Dr Anne Purdy, a pediatric cardiologist and the wife of Dr Emile Holman, 33rd AATS president, he performed cardiac procedures at the Children's Hospital 


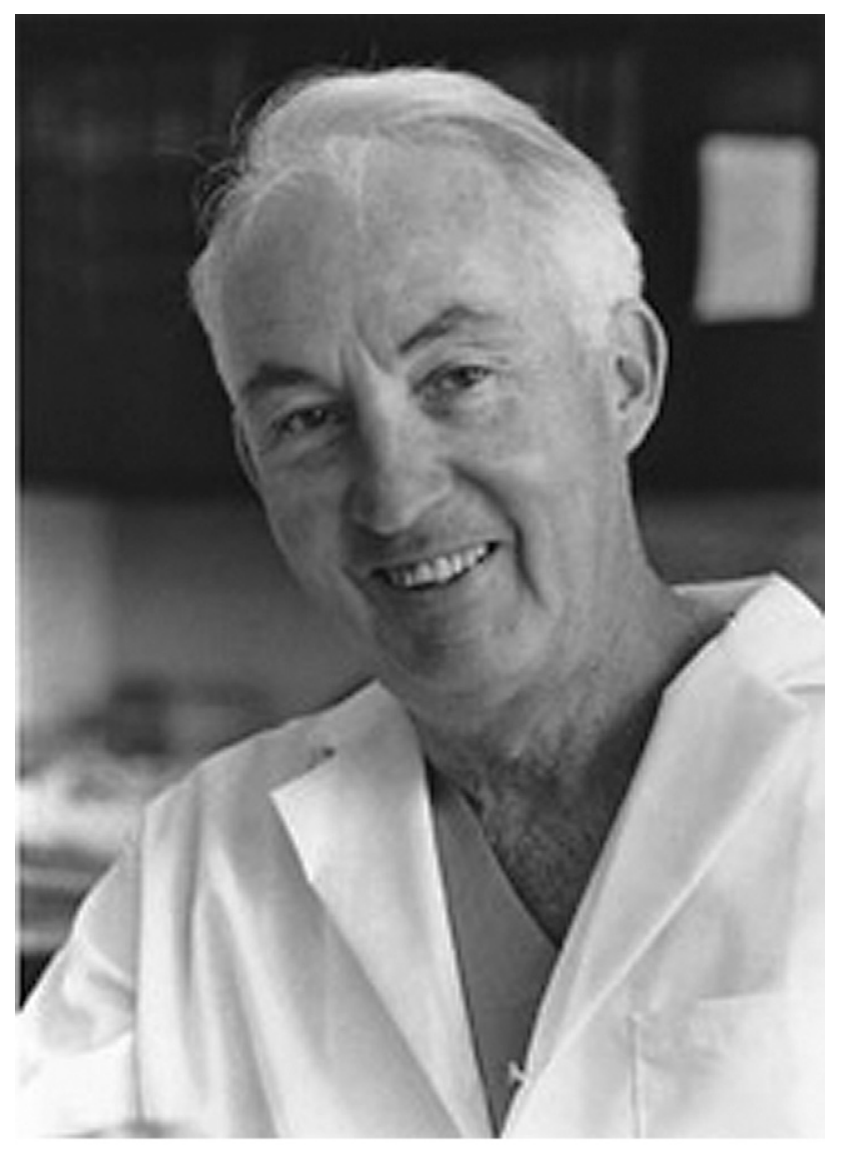

laboratory, they passed the time by attempting cardiac autotransplantation. Dr Shumway suggested, "We can cut it (the heart) out at the atrial level and put it in some cold saline and then suture it back in place." ${ }^{3}$ Because of a shortage of tissue after explant and surgical bleeding, Dr Shumway recalled that Dr Lower extended this technique to the use of a different dog for the donor heart. The ingenuity of modern heart transplantation thus originated "as sort of an accidental technique." In December 1959, the first long-term survival of a canine heart transplant was recorded. At the early morning session of the 1960 American College of Surgeons Surgical Forum, Dr Lower presented the series of 8 animals with 5 survivors ranging from 6 to 21 days and speculated that "if the immunologic mechanisms of the host were prevented from destroying the graft, in all likelihood it would continue to function adequately for the normal life of the animal"; to their disappointment, however, apparently Drs Shumway and Lower, along with the projectionist and the moderator, were the only ones in attendance. ${ }^{5,11}$

After 5 more years of intense research, Lower and Shumway's study comparing animals with and without immunosuppression, along with the use of decreased voltage on the electrocardiogram as evidence of rejection, was published in $1965 .{ }^{12}$ In this article, they noted that high-dose immunosuppression during periods of rejection led to prolonged survival. Recognizing other major obstacles, including the lack of a standardized definition of brain death and still unresolved immunologic issues, Dr Shumway announced on November 20,1967, that it was an appropriate time to proceed with human cardiac transplantation once a suitable donor and recipient could be found..$^{3,5,7,13}$ On December 3, 1967, Dr Christiaan Barnard performed the first human heart transplant in Capetown, South Africa, an event that was much glorified and criticized in both the lay and scientific presses and a feat made possible in part by the less stringent legislation regarding donor organs in that country. ${ }^{3,7}$ Previously trained in Minnesota with Dr Lillehei and with some contact with Dr Shumway during their residency, Dr Barnard had been introduced to the Shumway-Lower technique of heart transplant in the summer of 1966 when he was invited by Dr David Hume to the Medical College of Virginia to study rejection in kidney transplantation. ${ }^{1,2,3,7}$ Out of curiosity and by chance, Dr Barnard observed Dr Lower, who previously left Stanford to be chief of cardiac surgery at Medical College of Virginia, performing heart transplantation procedures in an adjoining laboratory. ${ }^{7}$

The distracting publicity surrounding the first human heart transplant led Dr Shumway to state with relief, "We don't need to worry about the press now. We can proceed quietly and say nothing until we report our first 10 cases in the surgical journals." ${ }^{14}$ It was not until January 6, bypass." 10 During the tedious waiting period in the
1968, that Dr Shumway was able to find the appropriate 
recipient-donor match and performed the first successful heart transplant in the United States and the fourth in the world. ${ }^{1,2,7}$ While administrative members of the transplant team were at a wedding reception, news of the impending transplant was leaked to the press by a reporter from the San Jose Mercury News who happened to be at the same reception. ${ }^{14}$ At the press conference after the historic event, Shumway carefully avoided raising false hopes, "We have reached first base perhaps, but the work is just beginning." In ensuing years, Dr Shumway cautioned that it was not the technical aspect, but "what happens later with regard to the containment of rejection that makes the real difference." 15

By 1971, among the more than 100 patients who had undergone heart transplantation worldwide, the approximate 1 -year survival was only $20 \% .^{1,3}$ Because of the discouraging early outcomes, heart transplant centers in the United States came under harsh scrutiny, and all but Stanford and Medical College of Virginia stopped performing this procedure. ${ }^{1-5,7}$ For nearly a decade, Dr Shumway and his team addressed the many challenges of heart transplantation, including organ preservation, effect of denervation, noninvasive detection of rejection with transvenous endomyocardial biopsy, and proper immunosuppression, including rabbit antithymocyte globulin and cyclosporine (INN ciclosporin). ${ }^{1-4,16}$ Not limited to transplantation, Dr Shumway was the author or coauthor of more than 500 scientific articles and book chapters. Dr Shumway's innovations included the first pulmonary valve autograft, initially implanted in the descending aorta of the dog as reported by Dr Lower ${ }^{17}$ and later experimentally sewn into the aortic annulus as reported by Dr Cree Pillsbury in 1966 (predecessors of the Ross procedure). ${ }^{18}$

At Stanford University, Dr Shumway became chief of the division of cardiac surgery in 1964, professor in 1965, and the first chairman of the new department of cardiovascular surgery in 1974, which he chaired until his retirement in 1993. ${ }^{1,2,4}$ Throughout his career, Dr Shumway insisted that the residents perform the operations as surgeons, stating on numerous occasions, "I might not be the best surgeon in the world, but I certainly must be the best first assistant." He was extremely supportive of the chief residents on his service and created an atmosphere that inspired his trainees. His attitude in the operating room was focused yet relaxed, so that the best patient care was maintained. During particularly enjoyable parts of an operation, he would delightfully remark, "Isn't this fun? Isn't this easy? What could be better? Nothing could be better! We should be paying the patient to do this."

With great humility and no tolerance for hubris, he was an inspiring presence and led by example. According to Dr William Brody, a trainee and president of the Salk Institute and former president of Johns Hopkins University, "Dr Shumway had the ability to get people to work harder for him than anyone I have ever seen and yet never did it with a directive or an unkind word. He always used humor and delegated responsibility." ${ }^{15}$ Dr Shumway stepped back from the spotlight and provided the trainees with academic opportunities and took pride in their accomplishments, reminiscent of his mentor at Minnesota. He cherished the fact that he had trained more than 90 accomplished surgeons and leaders in cardiac surgery, a living legacy to his personal and surgical philosophy. ${ }^{1,2,4,5}$ To this day, many often will "put a stitch in for the Boss" as the last suture of a coronary anastomosis.

While a resident at the University of Minnesota, Dr Shumway met Mary Lou Stuurmans, who was a public health nurse. ${ }^{1}$ They married in 1951, just before leaving for his stint in the Air Force. Dr Shumway and Mary Lou were blessed with 4 children, Michael, Lisa, Amy, and Sara, and 2 grandchildren. Michael is a certified public accountant and comptroller for a law firm. Lisa is a business development manager for a computer company. Amy is an artist. Sara is professor of surgery at the University of Minnesota and has coauthored with her father the textbook Thoracic Transplantation. ${ }^{19}$ Dr Shumway's marriage to Mary Lou ended in divorce. A day after his 83rd birthday on February 10, 2006, Dr Shumway died of complications from cancer in his home in Palo Alto. The memorial service held at the standing room only Stanford Memorial Church was attended by his family and friends, including many of his trainees, hospital and research staff, medical school and university personnel and officials, and former patients.

Along with work and family, Dr Shumway had another passion - the game of golf. As members of the "Senior Cardiovascular Surgical Society," he and his friends, including Drs John Ochsner, Denton Cooley, Benson Wilcox, Mortimer Buckley, James DeWeese, Jay Ankeney, George Magovern, Paul Ebert, and others, would meet annually at an appropriate golf resort. The culmination of Dr Shumway's golf career was his participation at the 1993 AT\&T Pebble Beach Pro-Am Tournament, with professional golfer Joe Durant as his partner and long-time friend and colleague Dr James Mark as his caddy.

In his presidential address at the AATS meeting in 1987 entitled, "Some Thoughts From the Other Side of the Table, or the Last Presidential Address," Dr Shumway humorously remarked, "with apologies to Paul Ebert [then Vice President] and his successors, the so-called Presidential Address should be abandoned. It is usually a summary of material already published and sometimes reveals more than we ever want to know about the incumbent. You will soon appreciate why this should be the last Presidential Address. It very definitely will be my last." ${ }^{\circ 9} \mathrm{He}$ described his philosophy of surgical education noting that "certainly it cannot matter as much who does the operation, as how it is done." He then provided an absorbing account of the many events and specific individuals that made cardiac and cardiopulmonary transplantation a reality. According 
to Dr Sara Shumway, he was particularly pleased with the amusement he generated with his comments at the meeting. ${ }^{5}$ Many witty "Shumwayisms" continue to be repeated almost daily in operating rooms around the world, such as "the pump is your friend," "just keep operating," and "he needs the usual 3 [bypasses]." Dr Ronald Dorfman, a good friend and then senior pathologist, recalled a meeting of the Stanford Medical Board to discuss requiring cardiopulmonary resuscitation training for faculty. Dorfman questioned whether it was necessary for pathologists to participate, "Quick as a flash, Norman responded, 'No! that's a conflict of interest!' which resulted in gales of laughter from committee members." 20

Reflecting on his career, Dr Shumway once told Dr O. H. Frazier that his was "one case where the Army aptitude test may have been right." 15 Dr Shumway's assistant Adena Goodart remembered him as one who had "no airs about him - what you saw was what you got. For one so brilliant and accomplished, he was extraordinarily humble. He treated everyone as his equal-he attended our department janitor's graduation ceremony just because he was invited." 20 A good friend summarized it best, "When I think of his career, it occurs to me that there are those who are risk takers and those who want a sure thing. Norm was one of those rare people who could take a risk and turn it into a sure thing. ${ }^{20}$ In 2004, when speaking about the first heart transplant, the author Donald McRae quoted Dr Shumway, "Maybe it was a blessing that we weren't the first. We had enough hassle dealing with the media and all that hoo-hah. Maybe, in the end, it all worked out for the best.... Yeah, I think it worked out just fine." 7 Perhaps it is fitting that his long-time friend Dr Lower should have the last word. Shortly before his death in 2008, Dr Lower recounted, "The work mattered more than anything. Maybe we started it off but so many fine people followed us. We did the work and we did our best. And so, like Norm, I can rest easy now."7

We acknowledge the following for their assistance and insights in preparing this profile: Drs Sara J. Shumway, Robert C. Robbins,
Bruce A. Reitz, D. Craig Miller, Philip A. Oyer, R. Scott Mitchell, Thomas A. Burdon, James B. D. Mark, and Lawrence H. Cohn.

\section{References}

1. Baumgartner WA, Reitz BA, Gott VL, Shumway SJ. Norman E. Shumway, MD, PhD: visionary innovator, humorist. J Thorac Cardiovasc Surg. 2009;137: 269-77.

2. Miller DC, Robbins RC. 1998 AATS Scientific Achievement Award recipientNorman E. Shumway, MD, PhD. American Association for Thoracic Surgery. J Thorac Cardiovasc Surg. 1999;118:783-6.

3. Stoney WS. Norman Shumway, MD, PhD. In: Pioneers of cardiac surgery. Nashville, TN: Vanderbilt University Press; 2008;427-39.

4. Robbins RC. Profiles in cardiology: Norman E. Shumway. Clin Cardiol. 2000; 23:462-6.

5. Shumway SJ. A tribute to Norman E. Shumway, MD, PhD (1923-2006). Heart Failure Clin. 2007;3:111-5.

6. Shumway NE. C. Walton and F. John. Ann Thorac Surg. 1999;68(3 Suppl): S34-6.

7. McRae D. History of heart transplantation. In: Kirklin JK, Mehra M, West LJ, eds. History of international heart and lung transplantation. Philadelphia: Elsevier; 2010;1-36

8. Shumway NE. F. John Lewis, MD: 1916-1993. Ann Thorac Surg. 1996;61:250-1.

9. Shumway NE. Some thoughts from the other side of the table, or the last presidential address. J Thorac Cardiovasc Surg. 2011;142:1296-8.

10. Shumway NE, Lower RR, Stofer RC. Selective hypothermia of the heart in anoxic cardiac arrest. Surg Gynecol Obstet. 1959;109:750-4.

11. Lower RR, Shumway NE. Studies on orthotopic homotransplantation of the canine heart. Surg Forum. 1960;11:18-9.

12. Lower RR, Dong E Jr, Shumway NE. Long-term survival of cardiac homografts. Surgery. 1965;58:110-9.

13. Shumway NE. Way is clear for heart transplant. JAMA. 1967;202:31-2.

14. Andreopoulos S. "We can proceed quietly": Former news chief recalls the media hoopla that surrounded Shumway's historic 1968 surgery. Stanford, CA: Stanford University School of Medicine; 2006. Available at: http://med.stanford.edu/ featured_topics/obituary/shumway/shumway-spyros.html. Accessed August 15, 2011.

15. Altman LK. Altman LK. Norman E. Shumway, 83, who made the heart transplant a standard operation, dies. The New York Times. February 11, 2006; Health section.

16. Oyer PE, Stinson EB, Jamieson SW, Hunt SA, Reitz BA, Bieber CP, et al. One year experience with cyclosporin A in clinical heart transplantation. Heart Transplant. 1982;1:285-90.

17. Lower RR, Stofer RC, Shumway NE. Autotransplantation of the pulmonic valve into the aorta. J Thorac Cardiovasc Surg. 1960;39:680-7.

18. Pillsbury RC, Shumway NE. Replacement of the aortic valve with the autologous pulmonic valve. Surg Forum. 1966;17:176-7.

19. Shumway SJ, Shumway NE, eds. Thoracic transplantation. Cambridge, MA: Blackwell Science; 1995.

20. Stanford University School of Medicine. Norman Shumway memorial guestbook. Available at: http://med.stanford.edu/featured_topics/obituary/shumway/ guestbook/. Accessed August 15, 2011. 